\title{
Public's Perception and Attitude of Herbal Medication for Respiratory Viral Infections
}

\author{
Yousef Ahmed Alomi*, iD Bsc. \\ Pharm, Msc. Clin pharm, BCPS, BCNSP, DiBA, \\ CDE Critical Care Clinical Pharmacists, TPN \\ Clinical Pharmacist, Freelancer Business \\ Planner, Content Editor and Data Analyst, \\ P.O.BOX 100, Riyadh 11392, Riyadh, SAUDI \\ ARABIA
}

Ghadeer Alhazmi, Department of Medicine and Surgery, College of Medicine, Umm Al-Qura University, Makkah, SAUDI ARABIA.

Murouj Almaghrabi,

Department of Medicine and Surgery, College of Medicine, Umm Al-Qura University, Makkah, SAUDI ARABIA.

Ghaida Alzahrani, Department of Medicine and Surgery, College of Medicine, Umm Al-Qura University, Makkah,

SAUDI ARABIA

Mohammad Almatrafi, (ID logo),

Department of Medicine and Surgery, College of Medicine, Umm Al-Qura University, Makkah, SAUDI ARABIA.

\section{Correspondence:}

Dr. Yousef Ahmed Alomi, BSc. Pharm, MSC. Clin Pharm, BCPS, BCNSP, DiBA, CDE Critical Care Clinical Pharmacists, TPN Clinical Pharmacist, Freelancer Business Planner, Content Editor, and Data Analyst, Riyadh, Saudi Arabia.

Phone no: +966 504417712

E-mail:yalomi@gmail.com

Copyright: () the author(s), publisher and licensee International Journal of Pharmacology and Clinical Sciences. This is an open-access article distributed under the terms of the Creative Commons

Attribution Non-Commercial License, which permits unrestricted non-commercial use, distribution, and reproduction in any medium, provided the original work is properly cited.

This is an open access article distributed under the terms of the Creative Commons AttributionNonCommercial-ShareAlike 4.0 License

Access this article online

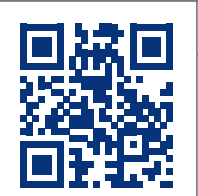

www.ijpcs.net

DOI:

10.5530/ijpcs.2021.10.21

\begin{abstract}
Background: The use of herbal-origin medications is overgrowing, snowballing belief in its absolute safety. However, some herbal medicines have revealed severe adverse events that may reach death. Hence, it is vital to understand the perception and attitude of patients towards using herbal medications. Objectives: This survey analysis goals to gauge patients' perceptions and attitudes towards herbal medicine to manage respiratory infections. Design and Settings: A self-administered, structured questionnaire was sent to the public online, counting questions on the responders' demographics and questions about different herbal medications and their use to treat viral respiratory infections. The survey also encompassed questions to evaluate patients' perceptions and attitudes towards the use of herbal medicine. Data analysis was implemented through SPSS program version 26. Results: Four hundred and eighty-six responders contributed in this questionnaire. 89.92\% of the responders were from the west area, and $94.62 \%$ had a Saudi nationality. 56.49\% were in the age group between 18 to 30 years old. $46.27 \%$ were students, while only $23.44 \%$ were employees. $53.69 \%$ had an income $<3000$ SR. $18.32 \%$ were healthcare practitioners, and $53.85 \%$ were physicians. $45.42 \%$ of the patients did not use herbal medications over the last year. $44.01 \%$ found herbal medicines effective and valuable, and $41.98 \%$ of the responders described herbal medicines as operative. Patients' gender ( $p$-value=0.025) significantly affected patients' perception of using herbal medications, where females showed a significantly better perception than females. The validity was tested by Mac (0.96), Cronbach (0.958), Guttmann 2 (0.961), and Guttmann 6 (0.973). Conclusion: The attitudes and perceptions of herbal medicine use among patients in Saudi Arabia are scarce. Awareness of the general public about herbal medications should be amended.
\end{abstract}

Key words: Public, Perception, Attitude, Herbal Medication, Viral Infections, Saudi Arabia

\section{INTRODUCTION}

In developing countries, most general population faith herbal products over the counter to manage common conditions, largely gastrointestinal and respiratory conditions. ${ }^{[1]}$ In the Middle East, the use of herbal medicine is snowballing, particularly in Saudi Arabia. Furthermore, many patients in advanced countries also prefer to use herbal-origin medications, believing that they are safer. Though, cautious use of herbal medicines should always be measured. ${ }^{[2,3]}$

The use of herbal medications is desired by patients and is measured by general practitioners and family medicine specialists. ${ }^{[4]}$ These medications are usually a first treatment option for mild and common conditions, like upper respiratory tract infections. This is established in the United States, where the use of herbal medications has augmented up to three-fold recently, while patients are using them without consulting their doctors. ${ }^{[5]}$ Also, up to half of the general population in developing countries favour herbal medications compared to chemical medications. ${ }^{[6]}$

In the Saudi community pharmacies, the patients can access a wide range of herbal supplements the counter products in different forms. ${ }^{[7]}$ Nevertheless, the attitude of the patients towards the use of these products is sometimes unsuitable. Most patients use herbal medicines based on their families and friends' endorsements without seeking medical advice. ${ }^{[8]}$ This behaviour accordingly exposes them to a noteworthy hazard of adverse events. ${ }^{[9]}$

Consequently, it is vital to understand the factors persuading patients' different perceptions and attitudes towards herbal medications. ${ }^{[10]}$ For example, some patients might be exaggerated by media advertisements about these agents, while others might be influenced by relative's or friends' experiences in a comparable condition. [11] Some patients also believe that doctors and pharmacists know only about chemical origins medications; hence they do not ask them about medicines of herbal origin. All these factors can lead to momentous complications and events that might harm the health of a large majority of the population. ${ }^{[12]}$

To present, data in Saudi Arabia on the general population's perception and attitudes towards the use of herbal medications for the treatment of viral respiratory infections is still indistinct. 
Consequently, the contemporary study intentions to discover Saudi perceptions and attitudes.

\section{MATERIALS AND METHODS}

\section{Study Design}

A quantitative, cross-sectional questionnaire study was achieved in Saudi Arabia through a self-administered electronic questionnaire dispersed to the general public over two months. All Saudi citizens were encompassed. On the contrary, incomplete responses or responses from outside Saudi Arabia were omitted.

\section{Data Collection}

An online self-developed questionnaire was disseminated to members of the public in all regions in Saudi Arabia. The survey encompassed demographic data (locations, gender, material status, age, responder qualifications, occupational status, and monthly income). Simultaneously, the second part of the questionnaire comprised questions on herbal medicine and its usages. Besides, the resources of information about herbal medications for respiratory viral infections. A 5-point Likert response scale system was used. The survey had been scattered to a convenient sample of public responders. It was through social Media of WhatsApp and telegram, and personal contact. The prompt message is sent every 1-2 weeks. The completed survey and Saudi public will be involved in the final analysis.

\section{Statistical Analyses}

According to the previous literature with unlimited population size, the sample was planned, the population percentage of $50 \%$, the confidence level $95 \%$ with $\mathrm{z}$ score of 1.96 and margin of error of $5 \%$ and drop-out rate of $10 \%$. As a result, the calculated sample size will equal a minimum sample of 418 with the power of study of $80 \% \cdot{ }^{[13-15]}$ The response rate compulsory of calculated sample size at least $60-70 \%$ and above. ${ }^{[15,16]}$ The survey was authenticated through the revision of expert reviewers and pilot testing. Besides, the reliability tests McDonald's $\omega$, Cronbach's a, Guttmann's 2, and Guttmann's six were completed with the study. The data analysis was finalized through the survey monkey system. Besides, the statistical package of social sciences (SPSS), Jeffery's Amazing Statistics Program (JASP), and Microsoft excel sheet version 16 with description and frequency analysis, good fitness analysis, correlation analysis, inferential analysis between independent variables responders. The STROBE (Strengthening the reporting of observational studies in epidemiology statement: guidelines for reporting observational studies) navigated the contemporary study's reporting. ${ }^{[17,18]}$

\section{RESULTS}

Four hundred and eighty-six responders contributed in this online questionnaire. Only participants who accomplished all the sections in the questionnaire were included. The questionnaire's reliability was tested through Mac (0.96), Cronbach (0.958), Guttmann 2 (0.961), and Guttmann 6 (0.973). Sociodemographics of responders and analysis of the questionnaire are shown below.

\section{General Characters of Responders}

Out of 486 participants, $89.92 \%$ of the responders were from the west area with statistically momentous differences with other regions $(p<0.001)$, and $94.62 \%$ had a Saudi nationality. Also, $80.45 \%$ were females with statistically significant differences from males $(p<0.001)$, where $59.17 \%$ were single. As for the age of the responders, it was characterised into seven sub-categories. The most dominant age group was between 18 and 30 years old, with $56.49 \%$ of the responses with statistically significant differences between age groups $(p<0.001)$. All socio-demographic data is shown Table 1.

\begin{tabular}{|c|c|c|c|}
\hline Nationality & Response Count & Response Percent & $p$-value \\
\hline Central area & 11 & $2.26 \%$ & \multirow[t]{5}{*}{$<0.001$} \\
\hline North area & 6 & $1.23 \%$ & \\
\hline South area & 20 & $4.12 \%$ & \\
\hline East area & 12 & $2.47 \%$ & \\
\hline West area & 437 & $89.92 \%$ & \\
\hline Answered question & 486 & & \\
\hline Skipped question & $\mathbf{0}$ & & \\
\hline Nationality & Response Count & Response Percent & \\
\hline Saudi & 457 & $94.62 \%$ & \multirow[t]{2}{*}{$<0.001$} \\
\hline Non-Saudi & 26 & $5.38 \%$ & \\
\hline Answered question & 483 & & \\
\hline Skipped question & 3 & & \\
\hline Gender & Response Count & Response Percent & \\
\hline Female & 391 & $80.45 \%$ & \multirow[t]{2}{*}{$<0.001$} \\
\hline Male & 95 & $19.55 \%$ & \\
\hline Answered question & 486 & & \\
\hline Skipped question & 0 & & \\
\hline Material Status & Response Count & Response Percent & \\
\hline Single & 284 & $59.17 \%$ & \multirow[t]{3}{*}{$<0.001$} \\
\hline Married & 187 & $38.96 \%$ & \\
\hline Divorced & 9 & $1.88 \%$ & \\
\hline Answered question & 480 & & \\
\hline Skipped question & 6 & & \\
\hline Age & Response Count & Response Percent & \\
\hline$<18$ & 32 & $6.60 \%$ & \multirow[t]{7}{*}{$<0.001$} \\
\hline $18-30$ & 274 & $56.49 \%$ & \\
\hline $31-40$ & 81 & $16.70 \%$ & \\
\hline $41-50$ & 58 & $11.96 \%$ & \\
\hline $51-60$ & 22 & $4.54 \%$ & \\
\hline $61-70$ & 15 & $3.09 \%$ & \\
\hline$>70$ & 3 & $0.62 \%$ & \\
\hline Answered question & 485 & & \\
\hline Skipped question & 1 & & \\
\hline
\end{tabular}




\section{Social and Professional Information of the Responders}

Regarding the responders' education level, $66.1 \%$ had a bachelor's degree, while $46.27 \%$ were still students, and only $23.44 \%$ were employees, with statistically significant differences $(p<0.001)$. Monthly income was also assessed; it has been shown that $53.69 \%$ had an income $<3000$ SR with statistically significant differences with other incomes $(p<0.001)$. Participants were also inquired if they were working in the medical field. Only $18.32 \%$ were healthcare practitioners, while $53.85 \%$ of these practitioners were physicians with statistically significant differences with other specialties $(p<0.001)$, as shown in Table 2.

\section{Herbal Medicine Used in Practice}

Responders were enquired about their thoughts on using some herbal medications for different indications. $80.39 \%$ of the responders thought that herbal medicines most commonly treat seasonal flu. Additionally, 45.42\% of the patients did not apply herbal medications over the last year, while $12.08 \%$ used them only once. The responders were also requested about their reasons for using herbal medicines. 44.01\% found herbal medications effective and useful. Based on their own involvements, $41.98 \%$ of the responders described herbal medicines as effective, as shown in Table 3.

\section{Perception of Patients towards the Use of Herbal Medications for Respiratory Viral Infections}

Responders were questioned about their perception and vision towards using herbal medications. They were probed to choose from five Likert scales, starting with "strongly agree" and ending with "strongly disagree." The average perception scores were (3.32) with a high score about educational lectures on herbal medications use for respiratory viral infection treatments (4.03), and the pharmacist should be educated and experienced about herbal medicines use for respiratory viral infection treatments (3.94). On the contrary, herbal medications' lowest scores do not interact with other medicines (2.75), and herbal medicines are safe and not dangerous for children (2.89).

Also, it was observed that more than a third of the responders were ambiguous about their opinion in all the questions related to their perception towards using herbal medications. There were statistically noteworthy differences between answers in all perception facets $(\mathrm{p}<0.001)$, as shown in Table 4 .

\begin{tabular}{|c|c|c|c|}
\hline Responder Qualifications & Response Count & Response Percent & $p$-value \\
\hline Doctorate & 10 & $2.08 \%$ & \multirow[t]{8}{*}{$<0.001$} \\
\hline Master's degree & 28 & $5.82 \%$ & \\
\hline Bachelor's degree & 318 & $66.11 \%$ & \\
\hline Diploma & 21 & $4.37 \%$ & \\
\hline High school & 99 & $20.58 \%$ & \\
\hline Intermediate School & 3 & $0.62 \%$ & \\
\hline Primary School & 1 & $0.21 \%$ & \\
\hline Not educated & 1 & $0.21 \%$ & \\
\hline Answered question & 481 & & \\
\hline Skipped question & 7 & & \\
\hline Occupational status & Response Count & Response Percent & \\
\hline Employee & 113 & $23.44 \%$ & \multirow[t]{4}{*}{$<0.001$} \\
\hline Non-employee & 109 & $22.61 \%$ & \\
\hline Retried & 37 & $7.68 \%$ & \\
\hline Student & 223 & $46.27 \%$ & \\
\hline Answered question & 482 & & \\
\hline Skipped question & 4 & & \\
\hline Monthly income & Response Count & Response Percent & \\
\hline$<3000 \mathrm{SR}$ & 233 & $53.69 \%$ & \multirow[t]{5}{*}{$<0.001$} \\
\hline 3001-6000 SR & 37 & $8.53 \%$ & \\
\hline 6001-9000 SR & 38 & $8.76 \%$ & \\
\hline 9001-12000 SR & 44 & $10.14 \%$ & \\
\hline$>12000 \mathrm{SR}$ & 82 & $18.89 \%$ & \\
\hline Answered question & 434 & & \\
\hline Skipped question & 52 & & \\
\hline $\begin{array}{l}\text { Are you a health care practitioner } \\
\text { (Medical Doctor- Dentist- Pharmacist- } \\
\text { Nurse- Others? }\end{array}$ & Response Count & Response Percent & \\
\hline Yes & 87 & $18.32 \%$ & \multirow[t]{2}{*}{$<0.001$} \\
\hline No & 388 & $81.68 \%$ & \\
\hline Answered question & 475 & & \\
\hline Skipped question & 11 & & \\
\hline $\begin{array}{l}\text { If you are a health care practitioner, } \\
\text { you are a }\end{array}$ & Response Count & Response Percent & \\
\hline Physician & 49 & $53.85 \%$ & \multirow[t]{4}{*}{$<0.001$} \\
\hline Dentist & 6 & $6.59 \%$ & \\
\hline Pharmacist & 8 & $8.79 \%$ & \\
\hline Nurse & 28 & $30.77 \%$ & \\
\hline Other (please specify) & 66 & & \\
\hline Answered question & 91 & & \\
\hline Skipped question & 395 & & \\
\hline
\end{tabular}

\section{Independent Variable Analysis} Age

There is no statistically momentous difference between males and females in different regions, ages, material status, nationality, healthcare provider or public, and healthcare professionals specialties $(p>0.05)$. In contrast, the male $12(63 \%)$ is higher than female $3(0.74 \%)$ in age 61 years old and above with statistically significant difference $(p<0.05)$. The male has higher academic qualifications than females master degree $12(12.77 \%)$ vs. $17(4.24 \%)$ or diploma 9 (9.57\% vs. 14 (3.49\%) while females 


\begin{tabular}{|c|c|c|c|}
\hline \multicolumn{3}{|c|}{ The Dental diseases or problems managed by herbal medications } & \\
\hline Answer Choices & \multicolumn{2}{|c|}{ Responses } & \\
\hline Coronavirus & 74 & $17.92 \%$ & \\
\hline Swine flu & 3 & $0.73 \%$ & \\
\hline Influenza A virus & 4 & $0.97 \%$ & \\
\hline Seasonal flu & 332 & $80.39 \%$ & \\
\hline Other (please specify) & 57 & $13.80 \%$ & \\
\hline Answered & 413 & & \\
\hline Skipped & 73 & & \\
\hline $\begin{array}{l}\text { How frequently have you used herbal } \\
\text { medications over the last } 12 \text { months for } \\
\text { respiratory viral management? }\end{array}$ & $\begin{array}{l}\text { Response } \\
\text { Count }\end{array}$ & Response Percent & \\
\hline never & 218 & $45.42 \%$ & \multirow[t]{7}{*}{$<0.001$} \\
\hline Once & 58 & $12.08 \%$ & \\
\hline twice & 57 & $11.88 \%$ & \\
\hline three times & 46 & $9.58 \%$ & \\
\hline four times & 25 & $5.21 \%$ & \\
\hline 5 to 9 five to nine times & 31 & $6.46 \%$ & \\
\hline ten times and more & 45 & $9.38 \%$ & \\
\hline Answered question & 480 & & \\
\hline $\begin{array}{l}\text { what are the reasons for using herbal } \\
\text { medications as a respiratory viral management }\end{array}$ & $\begin{array}{l}\text { Response } \\
\text { Count }\end{array}$ & Response Percent & \\
\hline effective and useful & 169 & $44.01 \%$ & \multirow[t]{7}{*}{$<0.001$} \\
\hline Safe & 108 & $28.13 \%$ & \\
\hline cheap & 17 & $4.43 \%$ & \\
\hline Easy to get it & 48 & $12.50 \%$ & \\
\hline based on the physician suggestion & 13 & $3.39 \%$ & \\
\hline lack of trust in manufactured medications & 26 & $6.77 \%$ & \\
\hline based on pharmacist suggestion & 3 & $0.78 \%$ & \\
\hline Answered question & 384 & & \\
\hline Skipped question & 102 & & \\
\hline $\begin{array}{l}\text { How did you find the herbal medications for } \\
\text { respiratory viral management }\end{array}$ & $\begin{array}{l}\text { Response } \\
\text { Count }\end{array}$ & Response Percent & \\
\hline Very effective & 73 & $17.22 \%$ & \multirow[t]{5}{*}{$<0.001$} \\
\hline Effective & 178 & $41.98 \%$ & \\
\hline Uncertain & 153 & $36.08 \%$ & \\
\hline Not effective & 14 & $3.30 \%$ & \\
\hline Not very effective & 6 & $1.42 \%$ & \\
\hline Answered question & 424 & & \\
\hline Skipped question & 62 & & \\
\hline
\end{tabular}

more had of bachelor's degree 271 (67.58\%) vs. $53(56.38 \%)$ with statistically significant difference $(p<0.05)$. The males more employed than female $32(34.04 \%)$ vs. 84 (20.9\%), and more retried 19 (2021\%) vs. 18 (4.48\%), while more females of non-employed 111 (27.61\%) vs. $8(8.51 \%)$ with statistically significant

\section{Healthcare Providers vs. Public}

There is no statistically momentous difference between responders healthcare providers and public residents in living regions, gender, nationality and monthly income $(p>0.05)$. However, the age of healthcare providers is higher than the public with (18-30 years) $72(80.9 \%)$ vs. $196(49.25 \%)$. In contrast, the people higher than professionals in ages (41-50 years) with percent $58(14.57 \%)$ vs. $1(1.12 \%)$, and age (51-60) with percent 22 (5.53\%) vs. $0(0 \%)$ with statistically significant difference $(p<0.05)$. Most healthcare professionals were single $70(80.46 \%)$ vs. public $208(52.66 \%)$, while the majority of public responders were married $180(45.57 \%)$ vs. healthcare professionals 16 (18.39\%) with statistically significant difference $(p<0.05)$. The healthcare providers had more bachelor's degree $70(79.55 \%)$ than public 248 $(62.78 \%)$, while the public had a more high school degree $90(22.78 \%)$ than healthcare providers $10(11.36 \%)$ with statistically important difference $(p<0.05)$. The public responders had more non-employment 106 (26.77\%) and retired 37 (9.34\%) than healthcare providers $12(13.64 \%)$ and $0(0 \%)$ respectively. In contrast, the healthcare providers had more student qualifications 56 (63.64\%) than public responders $160(40.4 \%)$, with a statistically substantial difference $(p<0.05)$.

\section{Nationality}

There is no statistically major difference between Saudi and non-Saudi in the different regions came from, ages group, gender, material status, educational levels, occupational status, monthly income, healthcare provider or public, and healthcare professionals specialties $(p>0.05)$.

\section{Independent Variable Correlation}

There is a confident association between age and material status and monthly income with spearman results (0.738) and (0.566) respectively, while the Kendal taw was (0.678), (0.499) with statistically weighty $(p<0.001)$. In contrast, there was a negative association between age and occupational status with spearman results $(-0.582)$ and Kendal taw $(-0.83)$ with statistically significant $(p<0.001)$. There was a positive connotation between material status and monthly income of spearman results was (0.518) and Kendal taw (0.476) with statistically significant $(p<0.001)$. While there was a negative correlation between material status and occupational level, spearman's results were $(-0.627)$ and Kendal taw $(-0.580)$ with statistically momentous $(p<0.001)$. There is a negative correlation between occupational levels and monthly income with spearman results $(-0.578)$ and 


\begin{tabular}{|c|c|c|c|c|c|c|c|c|c|c|c|c|c|}
\hline \multirow{2}{*}{$\begin{array}{l}\text { do you think herbal medication can } \\
\text { replace regular synthetic medications for } \\
\text { respiratory viral infection treatments }\end{array}$} & \multicolumn{2}{|c|}{$\begin{array}{l}\text { Strongly } \\
\text { agree }\end{array}$} & \multicolumn{2}{|c|}{ Agree } & \multicolumn{2}{|c|}{ Uncertain } & \multicolumn{2}{|c|}{ Disagree } & \multicolumn{2}{|c|}{$\begin{array}{l}\text { Strongly } \\
\text { disagree }\end{array}$} & \multirow{2}{*}{$\begin{array}{l}\text { Total } \\
467\end{array}$} & \multirow{2}{*}{$\begin{array}{c}\text { Weighted } \\
\text { Average } \\
3.01\end{array}$} & \multirow{2}{*}{$\begin{array}{l}\boldsymbol{p} \text {-value } \\
<0.001\end{array}$} \\
\hline & $10.28 \%$ & 48 & $16.92 \%$ & 79 & $39.83 \%$ & 186 & $27.41 \%$ & 128 & $5.57 \%$ & 26 & & & \\
\hline $\begin{array}{l}\text { do you think herbal medications can cure } \\
\text { respiratory viral diseases }\end{array}$ & $5.60 \%$ & 26 & $12.50 \%$ & 58 & $42.24 \%$ & 196 & $35.56 \%$ & 165 & $4.09 \%$ & 19 & 464 & 3.2 & $<0.001$ \\
\hline $\begin{array}{l}\text { do you think herbal medications do } \\
\text { not have any interactions with other } \\
\text { medications }\end{array}$ & $9.66 \%$ & 45 & $31.55 \%$ & 147 & $36.91 \%$ & 172 & $18.24 \%$ & 85 & $3.65 \%$ & 17 & 466 & 2.75 & $<0.001$ \\
\hline $\begin{array}{l}\text { do you think herbal medications are safe } \\
\text { and not dangerous for children }\end{array}$ & $8.37 \%$ & 39 & $26.18 \%$ & 122 & $37.12 \%$ & 173 & $24.25 \%$ & 113 & $4.08 \%$ & 19 & 466 & 2.89 & $<0.001$ \\
\hline $\begin{array}{l}\text { do you think herbal medications for viral } \\
\text { treatments are harmful to breastfeeding } \\
\text { women }\end{array}$ & $3.22 \%$ & 15 & $16.95 \%$ & 79 & $52.36 \%$ & 244 & $25.54 \%$ & 119 & $1.93 \%$ & 9 & 466 & 3.06 & $<0.001$ \\
\hline $\begin{array}{l}\text { do you think herbal medications for } \\
\text { respiratory viral infection treatments are } \\
\text { safe and effective for elderly }\end{array}$ & $2.15 \%$ & 10 & $9.66 \%$ & 45 & $40.34 \%$ & 188 & $39.06 \%$ & 182 & $8.80 \%$ & 41 & 466 & 3.43 & $<0.001$ \\
\hline $\begin{array}{l}\text { Herbal medications for respiratory } \\
\text { viral infection treatments should prove } \\
\text { their efficacy by studies and researches not } \\
\text { based on personal experiences }\end{array}$ & $4.08 \%$ & 19 & $7.94 \%$ & 37 & $28.97 \%$ & 135 & $33.91 \%$ & 158 & $25.11 \%$ & 117 & 466 & 3.68 & $<0.001$ \\
\hline $\begin{array}{l}\text { FDA and international organizations } \\
\text { should approve herbal medications for } \\
\text { respiratory use }\end{array}$ & $3.00 \%$ & 14 & $9.21 \%$ & 43 & $27.19 \%$ & 127 & $35.97 \%$ & 168 & $24.63 \%$ & 115 & 467 & 3.7 & $<0.001$ \\
\hline Answered & & & & & & & & & & & & 473 & \\
\hline Skipped & & & & & & & & & & & & 13 & \\
\hline
\end{tabular}

Kendal taw (-0.501) with statistically significant $(<0.001)$.

\section{DISCUSSION}

Herbal medications are gradually used for different mild community conditions, chiefly respiratory tract and oral infections. ${ }^{[19,20]}$ However, recently, some herbal medicines can lead to noteworthy side effects and complications. $^{[21]}$ Hence, patients should be aware of the hazards of using herbal treatments as well as their benefits. They should also be invigorated to seek medical advice before using any herbal products. ${ }^{[22]}$ During the pandemic period of various COVID-19 studies, viral infection was showed, underlining COVID19, either regular or herbal medications, with different results, positive or negative. All the inquiries search for the best and suitable medications for a viral illness, counting COVID-19. The patients sometimes do waiting until all clinical trials are completed. They used various regular and herbal medicines. The process of using any medications in practice starting knowing, then practice, and perception. The current study discovers the practice and perception of herbal medicines for viral infection. The present study intended to recognize the perception of patients living all over Saudi Arabia about the use of herbal medicines for acute respiratory tract infections. The study exemplified that's the majority of responders from west geographic area in Saudi Arabia. Besides, most of responders in a young age, student occupational status, single, and low monthly income because of the authors worked as data collectors, and they were students at college of medicine at Um Alora university located at west region and properly the most of composed from their society region. The characters of the sample study was entailed of two types. The majority part with public residents and one fifth of healthcare providers from total sample. The public was in elderly age, married, non-employments with low salary and without important an academic qualifications; while healthcare providers were young responders age, single, with employments, higher academic qualifications. Those descriptions was acknowledged and it was imitate the real life. Both groups, there were no statistically difference in gender or nationality, monthly income $(p<0.001)$. The responders' demographic data replicated the actual characters of Saudi populations. It might reproduced the actual behaviour of usage of 
herbal medications during viral infection with accent of coronavirus. There was medium positive correlation about age and marriage status, and linked with high financial income, while negative correlation of occupational status and younger age, and students positions correlation. In comparison; the old age connected with higher academic qualifications including mater science degree had negative association. Besides, the negative correlation of income and occupational status which echoed the reliable social practice.

The results should contain most responders who applied herbal medications for seasonal flu, followed by recently COVID-19. They used them at once for more than half of them. The patients specified reasons for using herbal medicines because of effective with valuable, and safe with easy to get it. This concept is widely dispersed for most public responders and agreed with numerous earlier studies. Besides, the responders tried the herbal medications, and more than half of them found the herbal medicines are effective, similar to other studies. However, the perception of herbal medicines is not unavoidably herbal effective in the clinical trials because several factors might mark the outcome in practice.

The perception of responders about herbal medications used for viral infection, counting COVID-19, was inadequate and compulsory further improvement. Similarly, Roy et al. ${ }^{[23]}$ examined Indian patient's and doctors' perceptions about using herbal medicines for different community indications. It exhibited a poor perception in both patients and doctors.

Although one-fifth of the included cohort were healthcare professionals, half of them did not use herbal medications over the last year. On the contrary, in patients who used herbal medicines, almost one-half found herbal medicines actual and treasured, and two-fifth of the responders defined herbal medications as effective. Furthermore, nearly half of the responders had a positive perception. Perception of the use of herbal medicines has been assessed in different settings. Foley et al. ${ }^{[24]}$ scrutinised the perception of patients towards using herbal medicines in clinical practice. A cross-sectional study that encompassed 252 patients, Foley et al. ${ }^{[24]}$ verified that patients strongly agree that they would prefer using herbal medications to treat common conditions compared to chemical origin medications.

Additionally, patients strongly settled that they should be denoted to a doctor or pharmacist to discuss their herbal medicines. On the contrary, Gupta et al. ${ }^{[25]}$ observed the perception of Indian patients towards using herbal medications. Gupta et al. ${ }^{[25]}$ involved 533 patients in a survey study and validated that the use of herbal medications among the included cohort was 56.6\%. However, most patients desired to try chemical medications and used herbal medications as a second-line or alternative.

In the existing study, half of the responders had the negative perception because there was no consciousness program about herbal medications, counting usage with a viral infection. The reports agreed with the perception of educational lectures about herbal use in respiratory viral infection demand, accentuating pharmacists to educate the patients about herbal medications for viral respiratory illness. It is imitated in the high demand for an education session about herbal medicines from most responders. In contrast, there was a poor insight of herbal medications during usage for children or any herbal drug interaction. It is related to the inadequate knowledge and awareness of herbal medicines for viral respiratory illness, including COVID-19. The usage of herbal medications was high by a respiratory viral infection in practice despite poor practice, perception and misapprehensions about them in Saudi Arabia. Additionally, the present study had some restrictions; the participants' responses depend largely on the responders' subjective opinion towards their use of herbal medications, which could move the reliability of the findings. Nevertheless, it is measured the first study in Saudi Arabia to assess patients' perception of herbal medicines for respiratory viral infection.

\section{CONCLUSION}

The Saudi population towards herbal medications is insufficient and needs further improvement. This perception can suggestively impact patients' behaviour and attitude towards using these medications and might distress their health. Hence, it is vital to carry out awareness sessions for the public about herbal medications' hazards and benefits through evidence-based medical information. In addition, additional studies are desired to observe the perception of patients towards using herbal medicines in other indications.

\section{ACKNOWLEDGEMENT}

None.

\section{CONFLICT OF INTEREST}

The authors declare that there is no conflict of interest.

\section{Funding}

None

\section{Consent for Publications}

Informed consent was obtained from all the participants

\section{Ethical Approval}

This research is exempted from research and ethical committee or an institutional review board (IRB) approval.

https://www.hhs.gov/ohrp/regulations-andpolicy/decision-charts-2018/index.html

\section{ABBREVIATIONS}

MOH: Ministry of Health; KSA: Kingdom of Saudi Arabia; Covid-19: Coronavirus; SPSS: Statistical Package of Social Sciences; JASP: Jeffery's Amazing Statistics Program; Strobe: Strengthening the reporting of observational studies in epidemiology statement: guidelines for reporting observational studies.

\section{ORCID ID}

Yousef Ahmed Alomi (iD https://orcid. org/0000-0003-1381-628X

Murouj Adnan Almaghrabi (D) https://orcid. org/0000-0001-7357-9269

\section{REFERENCES}

1. Waheida S, Lawend J, Basal AA, Shaaban R. Nursing students 'knowledge, practices, attitudes, and barriers toward complementary and alternative therapy. 2016;5(1):31-40.

2. Mousa HAL. Prevention and treatment of influenza, influenza-like illness, and common cold by herbal, complementary, and natural therapies. J Evid Based Complementary Altern Med. 2017;22(1):166-74. doi: 10.1177/ 2156587216641831 , PMID 27055821.

3. Leung PC, Ellie SYP, Karman Choi KPF. Health Promotion in relation to respiratory viral infections; 2008. In: Botanical medicine in clinical practice [internet]. Available from: https://books.google. com.sa/books?hl=en\&lr=lang_en\&id=j5PdVtMgV LYC\&oi=fnd\&pg =PA228\&dq $=$ Health + promotion + in+relation+to+respiratory+viral+infections\&ots= na2Ev_ObCT\&sig=D6U4BZeBfBOHJ8vLu9D772$\mathrm{mnGo} \&$ redir esc $=\mathrm{y} \# \mathrm{v}=$ onepage $\& \mathrm{q}=$ Health [cited 19/8/2021] promotion in relation to respiratory viral infections\&f=false.

4. Fintelmann V, Albrecht U, Schmitz G, Schnitker J. Efficacy and safety of a combination herbal medicinal product containing Tropaeoli majoris herba and Armoraciae rusticanae radix for the prophylactic treatment of patients with respiratory tract diseases: a randomised, prospective, double-blind, placebo-controlled phase III trial. Curr Med Res Opin. 2012 Nov;28(11):1799-807. doi: $\quad 10.1185 / 03007995.2012 .742048$, PMID 23083066.

5. Jayawardena R, Sooriyaarachchi P, Chourdakis M, Jeewandara C, Ranasinghe P. Enhancing immunity in viral infections, with special emphasis on COVID-19: a review. Diabetes Metab Syndr. 2020;14(4):367-82. doi: 10.1016/j.dsx.2020.04.015, PMID 32334392

6. van Andel T, Carvalheiro LG. Why urban citizens in developing countries use traditional medicines: the case of Suriname. Evid Based Complement Alternat Med. 2013;2013:687197. doi: 10.1155/ 2013/687197. 
7. McKimm-Breschkin JL, Jiang S, Hui DS, Beigel JH, Govorkova EA, Lee N. Prevention and treatment of respiratory viral infections: presentations on antivirals, traditional therapies and host-directed interventions at the 5th ISIRV Antiviral Group conference. Antiviral Res. 2018:149:118-42. doi: 10.1016/j.antiviral.2017.11.013, PMID 29162476.

8. Ershova IB, Osypova TF. Phytotherapy of acute respiratory viral diseases. Actual Infectol. 2017 Feb;0(4):73-82. doi: 10.22141/2312413x.4.13.2016.91460

9. Liu Q, Zhou YH, Ye F, Yang ZQ. Antivirals for respiratory viral infections: problems and prospects. Semin Respir Crit Care Med. 2016;37(4):640-6. doi: 10.1055/s-0036-1584803, PMID 27486742.

10. Harnett J, Oakes K, Carè J, Leach M, Brown D, Cramer H, Pinder TA, Steel A, Anheyer D. The effects of Sambucus nigra berry on acute respiratory viral infections: A rapid review of clinical studies. Adv Integr Med. 2020;7(4):240-6. doi: 10.1016/j.aimed.2020.08.001, PMID 32864330.

11. Li T, Peng T. Traditional Chinese herbal medicine as a source of molecules with antiviral activity. Antiviral Res. 2013;97(1):1-9. doi: 10.1016/j.antiviral. 2012.10.006, PMID 23153834.

12. Abd-Alla HI, Sweelam HM, El-Kashak WA, El-Safty MM. Evaluation of Immune Boosting Properties and Combating of Multiple Respiratory Viral Infections by fifteen Euphorbiaceae Plant Extracts. Pharmacogn J. 2019:11(6s):1490-503. doi: 10.5530/pj.2019.11.230.

13. Charan J, Biswas T. How to calculate sample size for different study designs in medical research? Indian J Psychol Med. 2013;35(2):121-6. doi 10.4103/0253-7176.116232, PMID 24049221.

14. Pourhoseingholi MA, Vahedi $M$, Rahimzadeh $M$. Sample size calculation in medical studies Gastroenterol Hepatol Bed Bench. 2013;6(1):14-7. PMID 24834239

15. Ezhumalai DG. How Big A Sample Do I Require? Annals of SBV. 2017;6(1):39-41. doi: 10.5005/jpjournals-10085-6113.

16. Johnson TP, Wislar JS. Response rates and nonresponse errors in surveys. JAMA 2012;307(17):1805-6. doi: 10.1001/jama.2012.3532, PMID 22550194.

17. von Elm E, Altman DG, Egger M, Pocock SJ, Gøtzsche PC, Vandenbroucke JP. The strengthening the reporting of observational studies in epidemiology (STROBE) statement: guidelines for reporting observational studies. PLOS Med. 2007;4(10):1623-7. doi: 10.1371/journal. pmed.0040296.

18. Von Elm E, Altman DG, Egger M, Pocock SJ, Gøtzsche PC, Vandenbroucke JP. The Strengthening the Reporting of Observational Studies in Epidemiology (STROBE) statement: guidelines for reporting observational studies. Available from: http://www.thelancet.com. Vol. 370; 2007.

19. Afzal S, Ahmad HI, Jabbar A, Tolba MM, AbouZid S, Irm N, Zulfiqar F, labal MZ, Ahmad S, Aslam Z. Use of medicinal plants for respiratory diseases in Bahawalpur, Pakistan. BioMed Res Int. 2021:2021:5578914 doi: 10.1155/2021/5578914.
20. Hameed M, Ashraf M, Al-Quriany F, Nawaz T, Ahmad MSA, Younis A, et al. Medicinal flora of the Cholistan desert: a review. Pak J Bot. 2011;43(2):39-50

21. Tabatabaei-Malazy O, Abdollahi M, Larijani B. Beneficial effects of anti-oxidative herbal medicines in diabetic patients infected with covid-19: A hypothesis. Diabetes Metab Syndr Obes. 2020;13:3113-6. doi: 10.2147/DMSO.S264824 PMID 32943897

22. Panyod S, Ho CT, Sheen LY. Dietary therapy and herbal medicine for COVID-19 prevention: a review and perspective. J Tradit Complement Med. 2020;10(4):420-7. doi: 10.1016/j.jtcme.2020.05.004, PMID 32691006.

23. Roy V, Gupta M, Ghosh RK. Perception, attitude and usage of complementary and alternative medicine among doctors and patients in a tertiary care hospital in India. Indian J Pharmacol. 2015 Mar;47(2):137-42. doi: 10.4103/02537613.153418, PMID 25878370.

24. Foley H, Steel A. Patient perceptions of patientcentred care, empathy and empowerment in complementary medicine clinical practice: A cross-sectional study. Adv Integr Med. 2017 Apr;4(1):22-30. doi: 10.1016/j.aimed.2017.02.006.

25. Gupta M, Shafiq N, Kumari S, Pandhi P. Patterns and perceptions of complementary and alternative medicine (CAM) among leukaemia patients visiting haematology clinic of a north Indian tertiary care hospital. Pharmacoepidemiol Drug Saf. 2002 Dec;11(8):671-6. doi: 10.1002/pds.782, PMID 12512243. 